\title{
СТРОЕНИЕ ГРЯДОВОГО РЕЛЬЕФА И ОСОБЕННОСТИ ДЕГЛЯЦИАЦИИ В РАЙОНЕ ОЗЕРА МАРТИМЪЯВР (КОЛЬСКИЙ ПОЛУОСТРОВ)
}

\author{
А. А. Вашков, О. Ю. Носова \\ Геологический институт КНЦ РАН, г. Апатиты \\ Поступила в редакцию 21 января 2019 г.
}

\begin{abstract}
Аннотация: в настоящей работе рассмотрены вопросы структуры, генезиса и механизма формирования грядового рельефа конечно-моренных образований, а также особенности дегляциации на севере Кольского полуострова. Исследованные конечно-моренные образования фиксируют одну из фаз отступления баренцевоморского потока последнего оледенения в среднем дриасе. В ходе работы применялся комплекс геологических, структурных и геоморфологических методов. Установлено, что грядовый рельеф сложен ледниковыми отложениями (абляционным и базальным тиллом), залегающими в виде складок и надвигов. В некоторых грядах обнаружены как дислоиированные, так и нормально залегающче флювиогляциальные отложения. Анализ текстур тиллов и ориентировки элементов гляциодислокаций указывает на передвижение ледника в восточном и северо-восточном направлении. Особенности геологического строения и морфологии грядового рельефа позволили выявить закономерности в плановом расположении отдельных ледниковых форм в виде цุепочек гряд. Эти цеепочки соответствовали нескольким осцилляциям фронта активного ледника с незначительным сокращением ледникового покрова. Таким образом, на севере Кольского полуострова периодически происходила смена ареальной дегляциации территории на фронтальную.
\end{abstract}

Ключевые слова: конечно-моренные образования, моренная гряда, гляциодислокации, базальный тилл, абляционный тилл, флювиоглящиальные отложения, дегляцииачи, ледниковая осцилляция.

\section{THE COMPOSITION OF RIDGE RELIEF AND DEGLACIATION FEATURES IN THE AREA OF THE MARTIMYAVR LAKE (THE KOLA PENINSULA)}

\begin{abstract}
: under consideration are issues of structure, genesis and formation mechanism of end-moraine deposits relief and deglaciation features on the north of the Kola Peninsula. Studied end-moraine deposits set one of the retreat phases of the Barents Sea Stream during the last glaciation in the Middle Dryas. Complex of geological, structural and geomorphological methods was used in this work. It was determined that the ridge relief is composed of glacial deposits (ablation and lodgement tills) lying in forms of faults and thrusts. Some ridges contain both dislocated and normal lying fluvioglacial deposits. Structure analysis of the tills and orientations of the glaciodislocation elements indicate that glacier moved to the east and north-east. Features of geological composition and ridge relief morphology allowed to reveal regularities in plane location of some glacial forms as ridges rows. These rows corresponded to several oscillations of active ice front with slight reduction of the ice cover. Thus on the north of the Kola Peninsula there was a periodic alternation of areal and frontal deglaciations.

Key words: end-moraine deposits, moraine ridge, glaciodislocations, lodgement till, ablation till, fluvioglacial deposits, deglaciation, glacier oscillation.
\end{abstract}

\section{Введение}

Среди аккумулятивных ледниковых образований Кольского региона особое положение занимают участки развития грядового рельефа со сложным морфологическим строением и плановым рисунком. Эти территории характеризуются сочетанием невысоких, извилистых в плане, валообразных гряд и разделяющих их изометричных понижений с озерными или заболоченными котловинами. Гряды имеют различную форму: спрямленную, подковообразную, S- образную и замкнутую в кольцо или овал. Отдельные гряды расположены параллельно друг другу или выстраиваются в выраженные цепочки.

В настоящий момент установлены две основные 
закономерности расположения грядового рельефа сложной конфигурации, непосредственно связанные с его генезисом и особенностями ледникового морфогенеза. Так, грядовый рельеф сложной конфигурации, который встречается в виде выраженных полос шириной от 2 до 25 км, протяженностью 50 и более километров, относится В. Я. Евзеровым и В. В. Колькой к конечно-моренным образованиям последнего оледенения [1-3]. Выявленные в структуре гряд надвиговые и складчатые гляциодислокации указывают, по мнению авторов, на участие в образовании грядово-ячеистого рельефа (авторское название) активного ледника. В дальнейшем В. Я. Евзеров связывал формирование линейно ориентированного грядовоячеистого рельефа с внешней полосой поясов краевых образований, на стыке активного и мертвого льда. Непосредственно район работ относится к Поясу II в интерпретации автора, а краевые образования здесь должны быть представлены напорными моренными грядами, возраст которых был отнесен к среднему дриасу $[2,4]$.

Практически идентичный по морфологии рельеф выявлен в Кольском регионе и в пределах изомет-

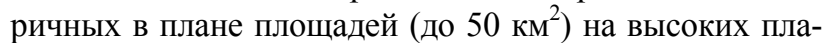
тообразных возвышенностях и склонах низких горных массивов региона во внутренних областях оледенения и в пределах ледораздельных зон [5-9]. Впервые такой рельеф был описан А. Д. Армандом и Н. Н. Арманд на северо-востоке региона и назван грядово-кольцевым [5, 6]. В строении гряд были установлены абляционные тиллы вытаивания [6]. Эти гряды находятся вне установленных цепей краевых образований и связаны с аккумуляциями мёртвого льда [7, 9].

В настоящий момент вопросы строения и происхождения сложного грядового рельефа в пределах конечно-моренных образований остаются дискуссионными. Наличие данных об участии в строении гряд краевых зон как дислоцированных базальных, так и абляционных тиллов может свидетельствовать о принципиально разном генезисе морфологически идентичных форм. Изучение морфологии и строения гряд представляет интерес с точки зрения расшифровки гляциодинамических процессов и типа дегляциации территории Кольского региона.

\section{Характеристика района исследования}

Район исследования расположен в северной части Кольского полуострова, в районе оз. Мартимъявр, бассейн р. Воронья (рис. 1). Эта территория относится к Мурманскому блоку кристаллического фундамента, представленного плагиогранитами, гранодиоритами и лейкогранитами вороньинского и центральнокольского комплексов. Поверхность коренных пород имеет глубину расчленения до 80-100 м, в её структуре выделяются выраженные поднятия, которые в современной поверхности проявляются в виде крупных холмов-массивов и высоких платообразных участков. Поднятия разделяются ложбинами и понижениями, в

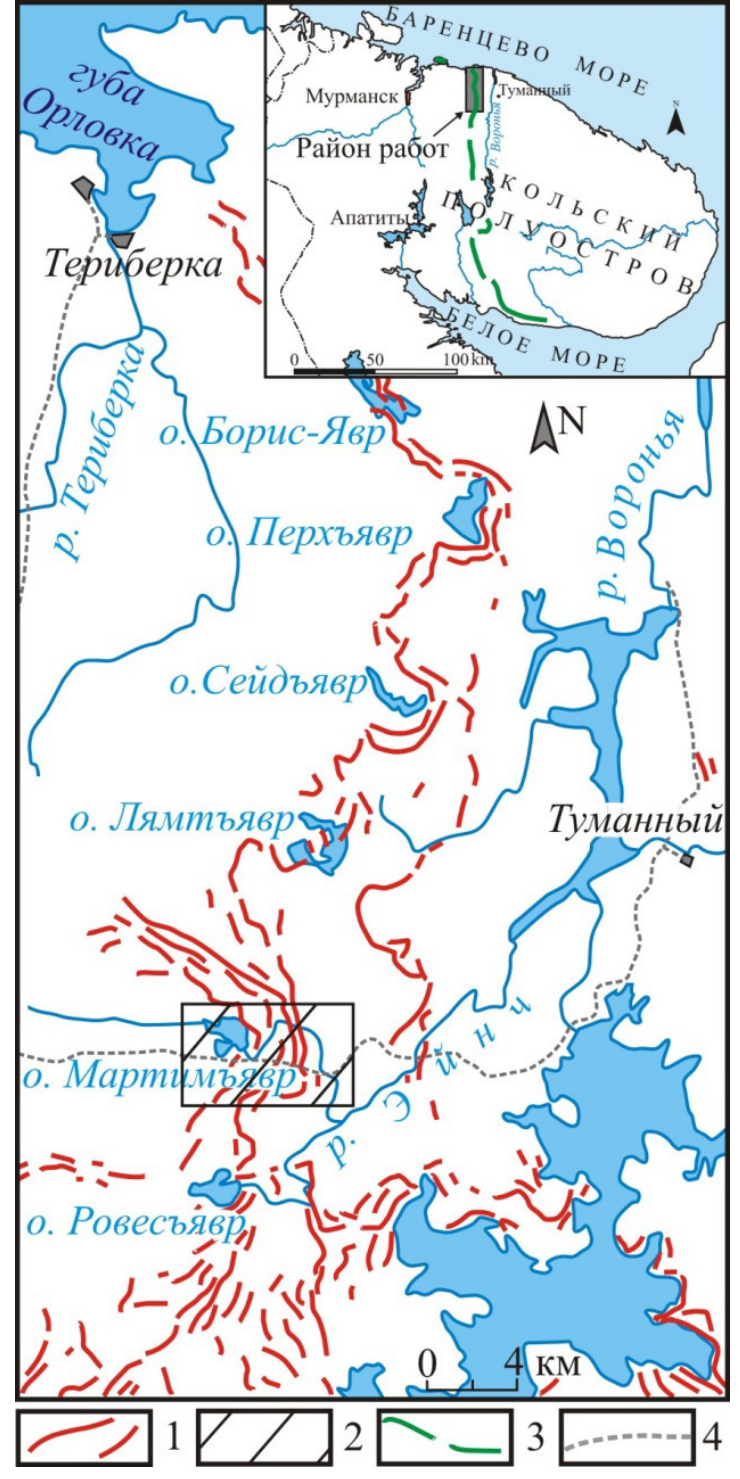

Pис. 1. Местоположение района работ: 1 - гряды ледникового происхождения; 2 - участок полевых работ; 3 - положение пояса II краевых образований (по [4]); 4 - автомобильные дороги.

пределах которых в современном рельефе часто выражены крупные озерные котловины.

Распределение мощности четвертичных аккумуляций находится в зависимости от рельефа поверхности кристаллического фундамента. В пределах понижений четвертичные образования района работ имеют относительно повышенную мощность до 20-25 м. На прилегающих к понижениям платообразных участках фундамента и на вершинах холмов-массивов мощность четвертичных аккумуляций обычно не превышает 1-3 м.

Четвертичные образования представлены преимущественно ледниковыми и флювиогляциальными аккумуляциями, которые надстраиваются комплексом современных озерных, аллювиальных и болотных осадков. Отложения ледникового ряда образуют грядовый рельеф, который локализован в пределах узкой 
полосы шириной 2-4 км и длиной 65-70 км. Эта полоса имеет в целом субмеридиональное простирание, протягивается от губы Орловка Баренцева моря (район п. Териберка) через понижения кристаллического фундамента с современными озерами Борис-Явр, Перхъявр, Сейдъявр, Лямтъявр, Мартимъявр. Далее к югу полоса выражена до котловины озера Ровесъявр, где сочленяется с полосой подобного рельефа субширотного простирания (рис. 1). Полоса грядового рельефа имеет фестончатый облик, в пределах понижений поверхности фундамента наблюдаются изгибы в восточном направлении. На склонах крупных холмовмассивов коренных пород, напротив, заметны отклонения грядового рельефа в западном направлении. Западнее района работ выражена платообразная равнина, восточнее расположен участок холмистой равнины, расчлененный глубокими долинами р. Воронья и её притоков. Район работ с запада на восток пересекает автомобильная дорога Мурманск - Туманный, что определяет наличие карьеров и выемок, вскрывающих гряды, а также хорошую транспортную доступность района работ.

\section{Методика исследований}

Новые данные о строении ледникового грядового рельефа и о механизме их формирования были получены с помощью геологических, структурных и геоморфологических методов.

Геологическими методами было изучено 11 искусственных обнажений (карьеры, расчистки на склонах гряд, шурфы). Проводилось подробное изучение структурно-текстурных особенностей ледниковых и водно-ледниковых осадков. Отмечались их цвет, гранулометрический состав, текстуры и наличие отдельных слоёв, линз, вкраплений. Производились замеры мощности отдельных слойков и линз, а также азимут и угол падения границ слоистости.

Для подтверждения генезиса и определения направлений нагнетания обломочного материала ледником применялся структурный метод массовых замеров плоскостных (плоскости сланцеватости, слоистости) и линейных (длинные оси галек и валунов) элементов тилла. Замеры производились при помощи геологического компаса, по 100 замеров азимутов и углов падения полюсов плитчатости и линейных элементов слоя. При исследовании складчатых структур тиллов замеры производились на крыльях и в ядре складок в равных соотношениях. При исследовании надвиговых гляциодислокаций отдельно исследовались структурные элементы толщ выше и ниже плоскости надвига. По результатам замеров с помощью программы OpenStereo 0.1.2, строились структурные диаграммы (использовалась нижняя полусфера и стереографическая сетка Вульфа). Анализ диаграмм начинался с выявления направления простирания осевой плоскости складки или плоскости надвига. Для этого устанавливалось пространственное расположение полюсов падения слоистости и плитчатости на крыльях и в ядре складки. Ориентировка полюсов в гляциоскладках обычно образует пояс максимумов. Расположение пояса указывает на тип складки (цилиндрическая или коническая), показывает направление нагнетания ледникового материала в складку или тело надвига, соответствующее плоскости смещения $S$ базальных ортотиллов [10]. В случаях анализа надвиговых гляциоструктур проекция плоскости надвига на нижнюю полусферу выносилась непосредственно на диаграмму падения полюсов плитчатости.

В дальнейшем полученная плоскость смещения $S$ условно переносилась на диаграммы ориентировки линейных элементов. В случаях, когда плоскости смещения соответствовал один или пара противоположных максимумов линейных элементов, устанавливалось направление $a$-линейности, которая указывает на перемещение галек и валунов согласно направлению движения льда. Если положение максимума или пары противоположных максимумов на диаграмме линейных элементов отличались на 75-90, устанавливалась $b$-линейность. Она соответствует оси главного нормального напряжения в теле перемещающего обломки ледника и указывает на наличие перпендикулярных направлению движения льда систем растяжения или сжатия. Если на диаграммах ориентировки линейных элементов обнаруживаются максимумы, не совпадающие с $a$ - и $b$-линейностью, то речь может идти о дополнительной системе напряжений в теле ледника, которая выражается на структурных диаграммах в виде дисперсии объемной линейности [10].

Геоморфологические методы заключались в сопоставлении геологических данных с формами рельефа, а также в морфометрических исследованиях рельефа. Прослеживание форм рельефа на местности проводилось в ходе маршрутной съемки с применением GPSнавигатора, рейки, рулетки, геологического компаса. Фиксировались морфометрические элементы форм рельефа (длина, ширина и высота гряд, протяженность и крутизна склонов, азимут простирания гребней). Были построены нивелирные ходы, использованные при построении геологических разрезов. В лабораторных условиях путем анализа цифровой модели рельефа ArcticDEM с разрешением в 5 м устанавливалось плановое расположение гряд.

\section{Результаты исследования}

Анализ полученной геологической и структурной информации показывает на участие в строении гряд нескольких типов гляциоструктур, которые построены как базальными ортотиллами, так и флювиогляциальными отложениями. На поверхности большинства форм залегает маломощная покрышка абляционного тилла.

Типичный разрез моренной гряды расположен в карьере у дороги Мурманск - Туманный (68 49' 08" с.ш. и $35^{\circ} 13^{\prime} 16^{\prime \prime}$ в.д., рис. 2, разрез № 1) [1-3]. Карьер вскрывает строение гряды длинной 0,18 км, шириной 18-30 м, с плоским гребнем шириной 3-6 м и крутыми склонами. Западный склон на $4-5^{\circ}$ круче восточного. Гряда ориентирована по азимуту $35-215^{\circ}$, 


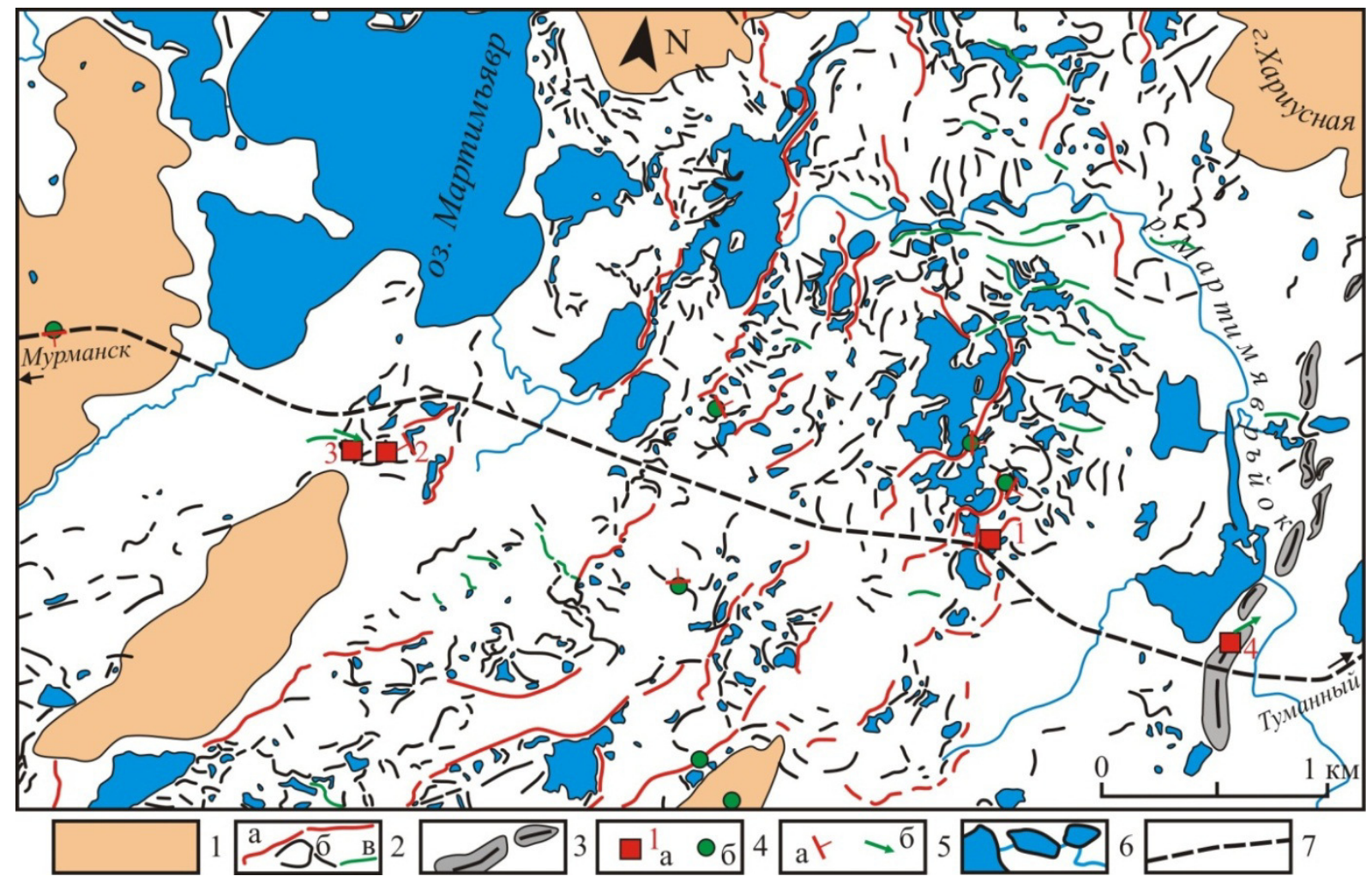

Рuc. 2. Морфологическая схема рельефа района работ: 1 - крупные холмы-массивы; 2 - гряды ориентированные (а), сложной плановой ориентировки (б), радиальные (в); 3 - гряды-увалы; 4 - изученные разрезы и их номера (а), расчистки и шурфы (б); 5 - элементы падения гляциодислокаций (а) и слоистости флювиогляциальных осадков (б); 6 - озера и реки; 7 автомобильная дорога.

линейная в плане, на севере изгибается к востоку. K западу от гряды расположено заболоченное понижение, за которым в 0,15-0,2 км прослеживается еще одна гряда со схожим обликом. К востоку от гряды выражена площадка, приподнятая на 1-1,5 м над заболоченными понижениями.

В строении гряды с поверхности участвует абляционный тилл в виде песчано-гравийной смеси с галькой и валунами (до 0,6 м в диаметре), коричневожелтой, в верхней части до светло-серой, на склонах гряды с ржаво-коричневыми пятнами ожелезнений. Интенсивность ржаво-коричневой окраски слоя убывает к подошве. Материал насыщен глинистыми частицами, не промыт, без признаков сортировки. Мощность слоя неравномерна, в западной части разреза $0,75-0,8$ м, в центральной части $0,35-0,4$ м, в восточной части - 0,25-0,3 м. Слой перекрыт маломощной современной почвой.

Ниже по разрезу залегает базальный тилл: песок серый с зеленоватым оттенком, глинистый, не промытый, разнозернистый, преимущественно мелкозернистый, с гравием, галькой, валунами до 1 м и больше, уплотненный. Песок имеет отчетливую плитчатую текстуру и слоистость. Слоистость выражена за счет тонких прослоев и линз песка светло-серого, разнозернистого, преимущественно мелкозернистого, с редким гравием. Толщина этих прослоев и линз от 12 мм до 2-3,5 см. Аналогичными осадками выполнены и нижние части ячеек крупных обломков. Также в слое присутствуют прослои и линзы песка бледнокоричневого, разнозернистого, мелко- и среднезернистого, с гравием, галькой и валунами, глинистого, уплотненного. Толщина этих включений неоднородна и достигает 25-28 см. Прослои и линзы залегают в слое преимущественно в виде складок, крылья которых ориентированы в разрезе аналогично слоистости по пескам светло-серым. Общая видимая мощность песков серых - более 2,5 м.

Характер падения плитчатых элементов и слоистости базального тилла изменяется в разных частях разреза (рис. 3). В западной части слоистость отчетливо наклонена по азимуту $255-275^{\circ}$, под углами $15-30^{\circ}$. В направлении центральной части гряды угол падения линейных элементов постепенно возрастает до 35-40 В центральной части разреза отчетливо выражен прослой песка светло-серого, который падает по азимуту $258^{\circ}$ и углом $44^{\circ}$. Ниже этого прослоя слоистость имеет принципиально иной характер залегания. Здесь она формирует ассиметричную складку с более крутым западным крылом. Западное крыло этой складки, залегает непосредственно под прослоем песка светлосерого центральной части разреза, а восточное, пологое крыло (азимут падения 75-90', угол падения до 20), формирует восточный склон гряды. Таким образом, по залеганию плитчатости и слоистости отчетливо выражены два типа гляциоструктур - гляционадвиг в центральной и западной части разреза и ассиметричная гляциоскладка в восточной части разреза. 

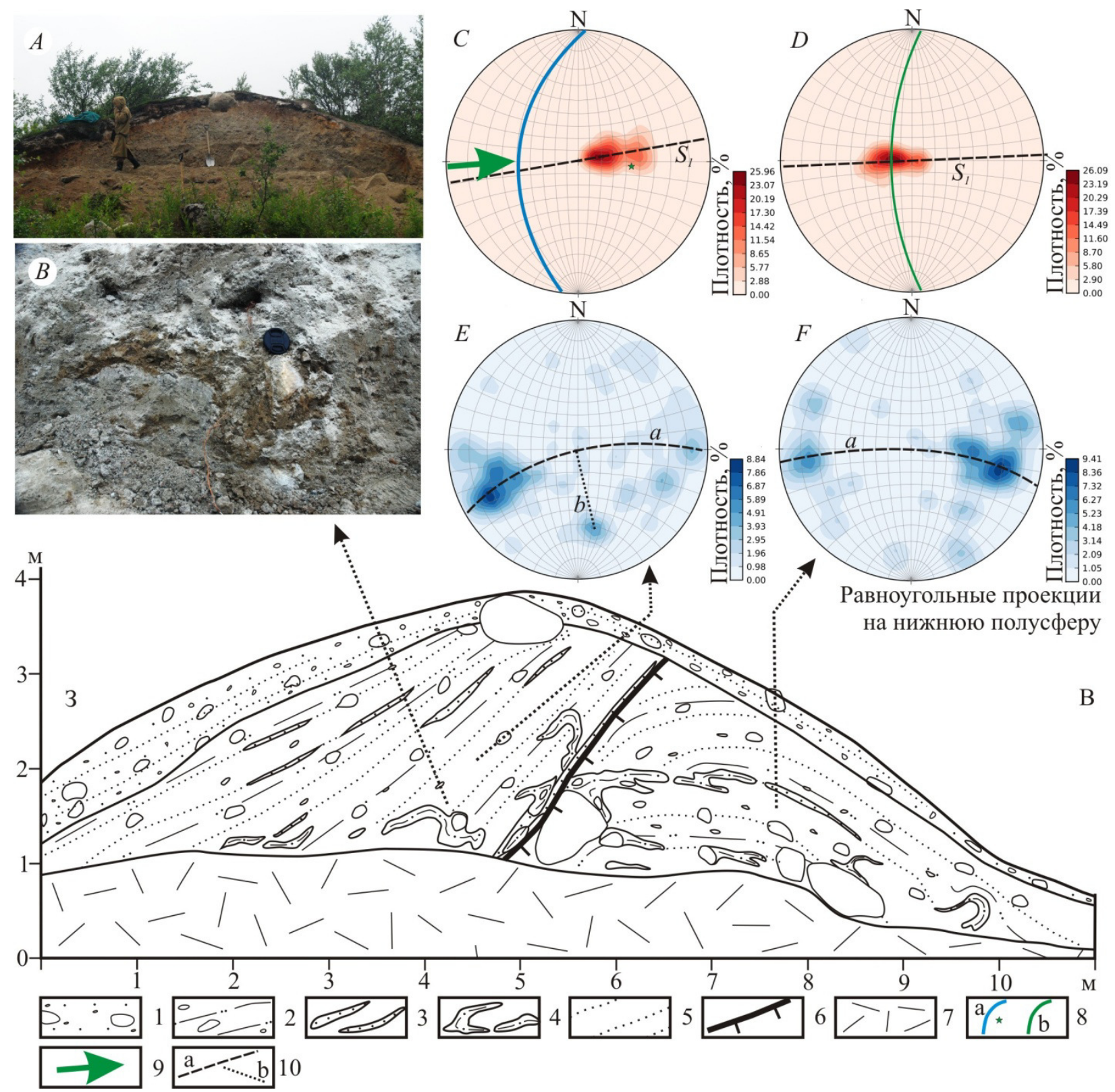

Pис. 3. Строение ориентированной гряды в разрезе № 1: 1 - песчано-гравийная смесь не сортированная; 2 - песок зеленовато-серый с гравием, галькой, валунами; 3 - песок тонкозернистый в линзах; 4 - песок желто-коричневый в лизнах; 5 - направление падения сланцеватости в песках зеленовато-серых; 6 - плоскость надвига; 7 - осыпь; 8 - полюс падения и проекция плоскости надвига (a) и проекция осевой плоскости складки (b); 9 - направление давления ледника; 10 - положение главной плоскости скольжения(a) и плоскости напряжений (b) на структурных диаграммах Е, F. Буквами обозначены: $A$ - общий вид разреза; $B$ - линза песка желто-коричневого; структурные диаграммы: $C$ - падение полюсов сланцеватости в блоке надвига, $D$ - падение полюсов сланцеватости в складке, $E$ - падение линейных элементов в блоке надвига, $F$ - падение линейных элементов в складке.

Гляциоструктура другого типа была изучена в карьере в 0,6 км к юго-востоку от оз. Мартимъявр (68 49' 20" с.ш. и $35^{\circ} 09^{\prime}$ 04" в.д., рис. 2, разрез № 2). Карьер вскрывает строение гряды длиной 0,14 км, шириной 12-18 м, высотой 2-4 м. В плане эта форма имеет серпообразную форму, в разрезе выпуклая, с уплощенным гребнем и ассиметричными склонами. Западный склон крутизной 28-32 склона на $8-14^{\circ}$. С востока к гряде примыкает площадка с общим уклоном от гряды. В 30 м к западу прослеживается еще одна гряда со схожей морфологией и строением.
В строении гряды установлены две пачки отложений, залегающие несогласно. В первую пачку входят флювиогляциальные отложения: песчано-гравийногалечная смесь с валунами, коричнево-желтая, с пятнами ожелезнений, с неоднородным содержанием глинистых частиц по слою, не промытая, грубая, не сортированная (рис. 4 , слой 1 ), а также песчано-гравийно-галечная смесь с валунами, желто-серая, с почти полным отсутствием глинистых примесей, средней степени промывки, почти не сортированная (слой 2 на рис. 4). Крупные обломки в составе смеси хорошей и средней степени окатанности. Аккумуляции 

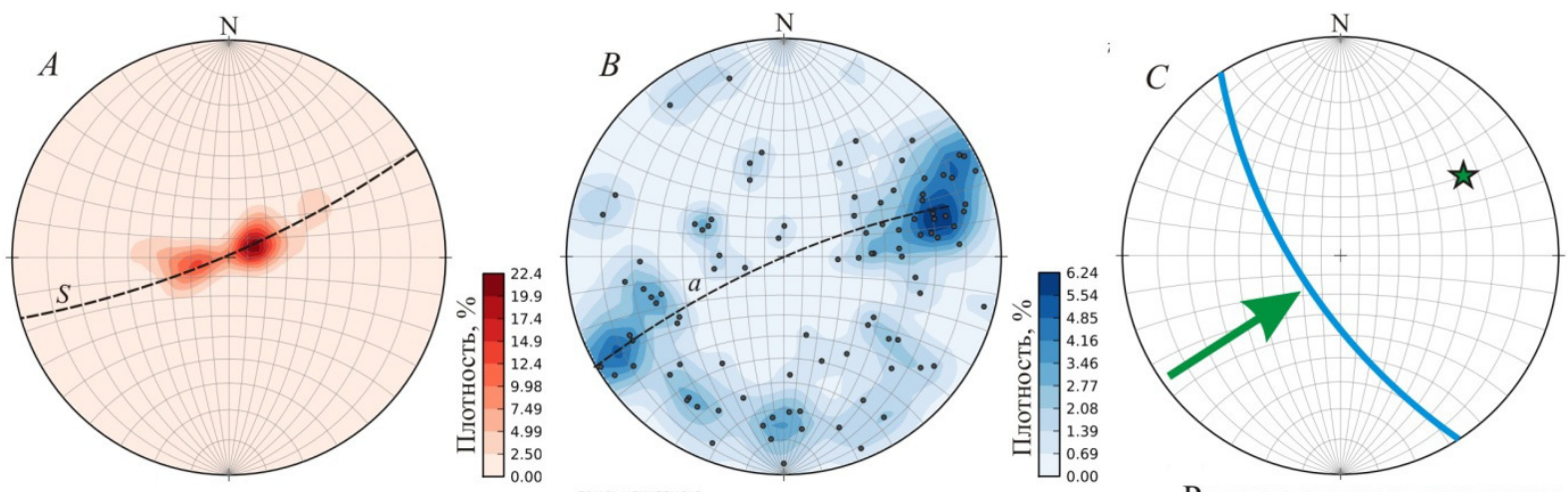

Равноугольные проекции

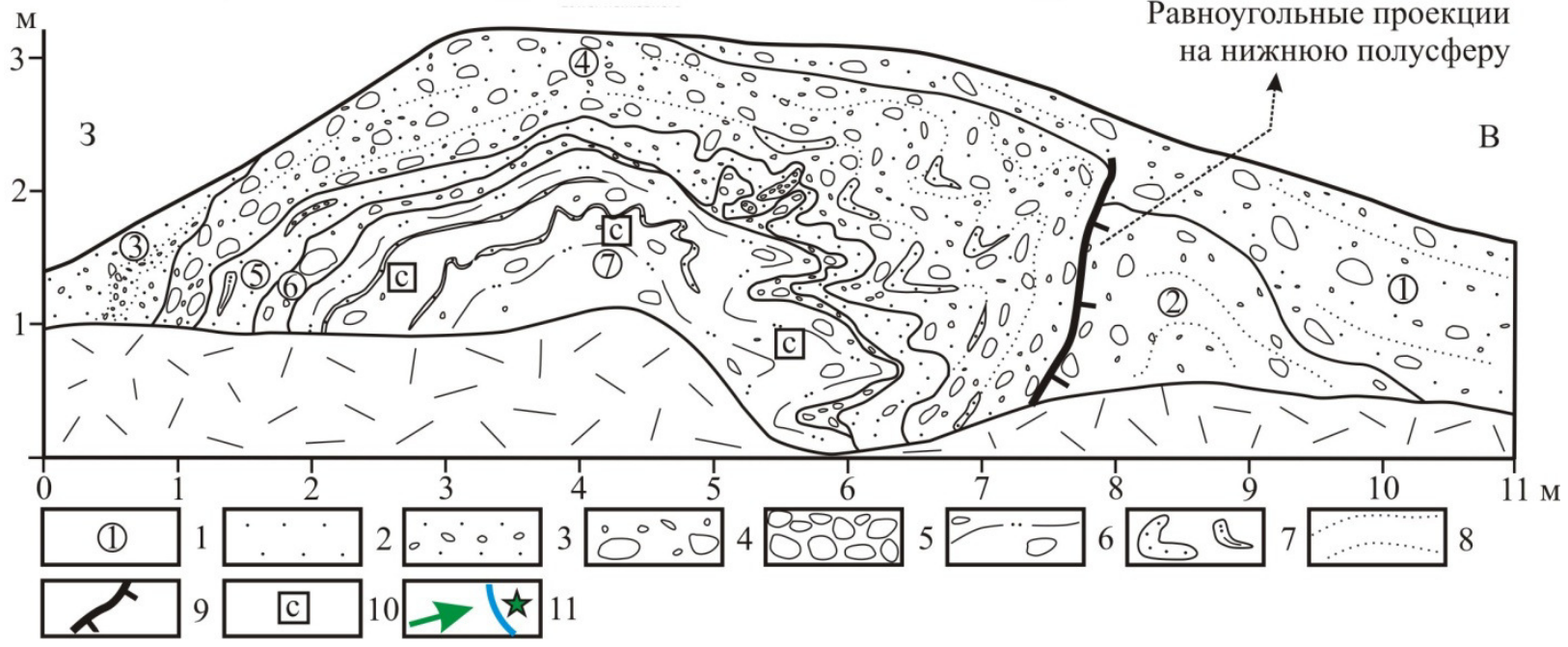

Puc. 4. Строение гряды сложной плановой ориентировки в разрезе № 2: 1 - номера слоев; 2 - песок разнозернистый; 3 песчано-гравийная смесь; 4 - гравийно-галечная смесь; 5 - галечно-валунная смесь; 6 - песок зеленовато-серый и галькой и валунами; 7 - песок разнозернистый в линзах; 8 - направление падения слоистости; 9 - плоскость надвига; 10 - места структурных исследований песков в ядре складки; 11 - направление давления ледника, проекция и падение полюса плоскости надвига. Буквами обозначены структурные диаграммы: $A$ - падение полюсов слацеватости и слоистости в складке; $B-$ падение линейных элементов в складке; $C$ - падение плоскости надвига.

этой пачки имеют признаки плохо прослеживающейся слоистости. Отмечаются прослои песка коричневожелтого, разнозернистого, преимущественно среднезернистого, ожелезненного. Эти прослои падают по азимуту $105-118^{\circ}$ и под углом $14-17^{\circ}$. Отложения первой пачки развиты только на восточном склоне гряды, где их мощность составляет более 2,5 м.

С запада на эти аккумуляции надвинуты флювиогляциальные отложения второй пачки. Зона надвига падает по азимуту $237^{\circ}$ и под углом $68^{\circ}$ (рис. 4, С). Крупнообломочный материал второй пачки вдоль этой зоны сцементирован железистым цементом. Отложения второй пачки залегают в виде ассиметричной складки. На крыльях и в замковой части залегают флювиогляциальные осадки (рис. 4, слои 3-6), представленные переслаиванием песчано-гравийно-галечной смеси коричнево-желтой с валунами, песков желто-коричневых, разнозернистых, преимущественно мелкозернистых и песчано-гравийной смеси коричнево-желтой. Эти отложения характеризуются средней и слабой степенью промывки и сортировки. Крупные обломки преимущественно средне и хорошо окатанной формы. В песчаных отложениях наблюдаются включения песка серого с зеленоватым оттенком, глинистого, с гравием и галькой, уплотненного, аналогичного отложениям, залегающим в ядре складки. Падение слоистости на западном крыле складки отмечается в юго-западных румбах (азимуты от 236$246^{\circ}$ ) под углами от $38^{\circ}$ до $68^{\circ}$. В замковой части залегание слоев облекающее относительно ядра складки. Общая мощность этих аккумуляций на западном крыле и в замке складки составляет 1-1,4 м. На восточном крыле флювиогляциальные отложения залегают запрокинуто, здесь же их мощность увеличивается до 1,6-2 м. Залегание осложняется многочисленными острыми, клинообразными, лежачими складками, с высотой крыльев до 0,7 м. Осевые плоскости таких складок расположены субгоризонтально. Ниже по разрезу флювиогляциальные отложения восточного крыла падают под углами $65-85^{\circ}$ в западном направлении.

В ядре складки установлен базальный тилл. Он представлен песком серым, с зеленоватым оттенком, глинистым, переходным к супеси, с гравием, галькой, валунами. Пескам характера сланцеватость и слоистость. Слоистость выражена за счет прослоев песка светло-серого, мелкозернистого, лучше всего 
проявляется в замковой части гляциоструктуры. На крыльях складки прослои распадаются на отдельные линзы, а глинистые пески иногда приобретают желто-серую окраску в виде пятен диаметром до $1 \mathrm{~cm}$. Мощность глинистых песков в ядре складки - более 1,8 м. Структурный анализ плоскостных и линейных элементов сланцеватости и слоистости базального тилла обнаруживает распределение максимумов ориентировки в виде изогнутого пояса (рис. 4, А, В). Такой рисунок характерен конической гляциоскладке с падением западного крыла по азимуту $239^{\circ}$ и восточного крыла по азимуту $78^{\circ}$. Шарнир складки погружается под углом $5^{\circ}$ в юго-юго-восточном направлении по азимуту $162^{\circ}$.

Анализ строения других гряд района исследования в шурфах и расчистках показывает преобладание в их строении базального тилла в виде песков серых, зеленовато-серых, глинистых, с гравием и галькой с заметной сланцеватой текстурой и тонкими прослоями песков светло-серых, мелкозернистых. Слоистость и сланцеватость в песках серого цвета часто имеет падение согласно склонам гряд, что может свидетельствовать о преобладании складчатых гляциодислокаций в структуре большинства гряд района исследований. Осадки абляционного тилла, представленные песками желто-серыми, коричнево-серыми, разнозернистыми, с гравием и галькой, плохой степени сортировки материала, залегают, как правило, облекающее и не имеют ведущего рельефообразующего значения.

Исключительно флювиогляциальными аккумуляциями построена меньшая часть гряд, как правило, субширотной ориентировки. Разрез одной из таких форм длиной более 60 м, шириной 10-15 м и высотой до 2-3 м изучен в бывшем карьере (68 49' 20" с.ш. и $35^{\circ} 08^{\prime}$ 51" в.д., рис. 2, разрез № 3). Здесь вскрыт не упорядоченный и плохо сортированный грубообломочный материал. На поверхности гряды залегает валунно-галечный материал с заполнителем в виде не сортированного песка и гравия, средней степени промывки. Крупные обломки преимущественно хорошо окатанной формы. Отложения без видимой слоистости, мощностью до 1,5 м. Ниже выявлен песчаногравийно-галечный материал с валунами. Заполняющий материал песок имеет желтовато-серый цвет. Эти осадки имеют лучшую степень сортировки и обретают черты слоистости, падающей по азимуту $92^{\circ}$ и углом $7^{\circ}$. Крупные обломки в слое хорошо окатанной формы.
Подобный по составу флювиогляциальный материал выявлен и в строении гряд-увалов с плоскими вершинами к востоку от участка развития моренных гряд. Так, в заброшенном карьере (68 $48^{\prime}$ 57" с.ш. и $35^{\circ} 13^{\prime}$ 50" в.д., рис. 2, разрез № 4), который вскрывает строение гряды, вытянутой с севера на юг, выявлены гравийно-галечно-валунные смеси, слабо сортированные, с примесью глинистых частиц. Крупные обломки средне и хорошо окатанной формы. Среди крупнообломочного материала отмечаются включения песчано-гравийно-галечных смесей в виде линз длинной до 1 м, толщиной до 0,25 м. Слоистость внутри этих линз имеет уклон в северо-восточных румбах (азимут 53). Мощность флювиогляциальных аккумуляций здесь более 3 м. Поверхность гряды у карьера с большим скоплением валунов диаметром до 2,5 м.

Западнее участка развития грядового рельефа в пределах моренной равнины ледниковые отложения имеют двучленное строение. На поверхности залегают абляционные тиллы вытаивания: пески коричневожелтые, часто ожелезненные, глинистые, разнозернистые, с гравием, галькой, валунами, не сортированные. Мощность песков не превышает 0,5 м, но может повышаться в пределах небольших валообразных поднятий до 1-1,2 м. Под ними вскрыты базальные тиллы в виде песков серых, с зеленоватым оттенком, разнозернистых, преимущественно мелкозернистых, глинистых, слоистых, с выраженной сланцеватой текстурой. Сланцеватость имеет уклоны под углами 10$15^{\circ}$ с падением преимущественно в южных румбах (азимуты 157-174'). Пески слоистые, с тонкими линзами алеврита однородного, зеленовато-серого, песка серо-желтого, мелкозернистого, глинистого.

По морфометрическим показателям и рисунку планового расположения форм в ледниковом рельефе у котловины оз. Мартимъявр обнаруживается ряд закономерностей. Наиболее высокие и протяженные гряды, выраженные в рельефе за счёт надвиговых и складчатых гляциоструктур, выстраиваются в линейно вытянутые цепочки, которые прослеживаются параллельно друг другу (рис. 2). Они имеют преимущественно меридиональную ориентировку и, как будет сказано ниже, фиксируют положение фронта активного ледника. Эти фронтальные гряды обладают специфическими морфометрическими показателями, отличающими их от других форм исследуемой территории - максимальной длиной и высотой, а также наиболее крутыми склонами (табл. 1).

Таблица 1

Основные морфометрические показатели грядового рельефа района котловины оз. Мартимъявр

\begin{tabular}{|c|c|c|c|c|c|c|}
\hline Типы гряд & $\begin{array}{c}\text { Длина } \\
\text { гряд, м }\end{array}$ & $\begin{array}{c}\text { Ширина } \\
\text { гряд, м }\end{array}$ & $\begin{array}{c}\text { Высота } \\
\text { гряд, м }\end{array}$ & $\begin{array}{c}\text { Длина } \\
\text { склонов, м }\end{array}$ & $\begin{array}{c}\text { Средняя кру- } \\
\text { тизна склонов }\end{array}$ & $\begin{array}{c}\text { Отношение длины } \\
\text { гряд к ширине }\end{array}$ \\
\hline Фронтальные & $150-1200$ & $15-70$ & $4-12$ & $5-32$ & $20-38^{\circ}$ & $10: 1-20: 1$ \\
\hline Кольцевые & $100-450$ & $12-50$ & $2-6$ & $4-23$ & $15-27^{\circ}$ & $7: 1-12: 1$ \\
\hline Радиальные & $100-800$ & $20-100$ & $2-8$ & $6-44$ & $10-16^{\circ}$ & $4: 1-10: 1$ \\
\hline Гряды-увалы & $400-750$ & $80-300$ & $4-10$ & $30-120$ & $5-10^{\circ}$ & $2,5: 1-6: 1$ \\
\hline
\end{tabular}


Цепочки фронтальных гряд отстоят друг от друга на расстоянии 0,25-0,8 км, непосредственно за пределами района работ расстояние между ними может увеличиваться до 0,8-1,7 км. Всего в районе работ установлено не менее шести параллельных цепочек. При пересечении их долиной р. Мартимяврьйок цепи гряд выгнуты в восточном направлении. На севере района работ цепи гряд примыкают к западному склону крупного холма-массива с абсолютными отметками 260 312 м (г. Харуисная), после чего три цепочки отходят в северо-северо-восточном направлении, а остальные - в северо-западном. В южном направлении к котловине о3. Ровесъявр цепочки гряд прослеживаются в основном параллельно друг другу, огибая с запада склон холма-массива высотой 220-265 м.

Между фронтальными цепочками расположены кольцевые гряды подковообразной, S- образной и округлой формы (в плане), которые отличаются от фронтальных гряд меньшей длиной и высотой. Понижения между этими грядами заняты небольшими озерными и заболоченными котловинами. Иногда кольцевые гряды сливаются друг с другом и образуют небольшие всхолмленные массивы.

Субширотно ориентированные гряды, построенные флювиогляциальными осадками, отнесены нами к радиальным грядам. Эти гряды, как правило, спрямленные или слабоизвилистые, крупнейшие из них тяготеют к наиболее низким участкам района работ. Восточнее участка распространения фронтальных и кольцевых гряд прослеживается прерывистая полоса гряд-увалов, которые далее в направлении долины р. Воронья сменяются расчлененным рельефом коренных пород с отдельными холмами-массивами и площадками долинных зандров в понижениях. На западе районе работ расположена моренная равнина с амплитудой расчленения ледникового рельефа 1-3 м. Равнина развита преимущественно на более высоком ярусе рельефа с абсолютными отметками 210-240 м и выше, а также на платообразной поверхности крупных холмов-массивов и их склонах.

\section{Обсуждение результатов и выводы}

Начало формирования грядового рельефа в районе озера Мартимъявр связано со стабилизацией края одной из лопастей баренцевоморского потока скандинавского ледникового покрова в среднем дриасе $[2,4]$ или, по другим сведениями, в позднем дриасе [11]. Относительно маломощный активный ледник продвигался в исследуемом районе по территории со сложным, расчлененным рельефом ледникового ложа с юго-запада, что установлено при исследовании элементов падения гляциоструктур. Конфигурация цепочек фронтальных гряд указывает на то, что край активного ледника имел фестончатый облик, вблизи краевой зоны происходило его разделение на множество отдельных языков. В роли ледоразделов отдельных языков выступали крупные холмы-массивы выступов кристаллического фундамента. Непосредственный край ледника в районе работ маркируется полосой гряд-увалов и флювиогляциаль- ными аккумуляциями за их дистальным склоном [1-3]. Установленные в составе гряд-увалов грубообломочные несортированные осадки позволяют связать их образование с абляционным тиллом перлювиальной фации, поступившего сюда путем сползания и оплывания с края ледника. Включения в их состав материала со следами переработки в водной среде указывают на проходившую в этой зоне и флювиогляциальную аккумуляцию. В то же время признаков гляциотектонической переработки этих осадков в районе работ не выявлено.

Во внутренней зоне активного ледникового покрова проходила аккумуляция базальных тиллов с характерной для Кольского региона зеленовато-серой окраской и сланцеватой и слоистой текстурой, указывающей на условия вязко-пластичного течения насыщенного дебрисом льда $[10,12-14]$. Насыщение базальных тиллов включениями песков бледно-коричневого цвета в виде небольших линз-отторженцев может указывать на активную ассимиляцию нижней частью активного ледника рыхлых пород ложа с их интенсивным вовлечением в состав гляциоструктур (рис. 3, В). Значительная неоднородность структуры ледника приводила к гляциотектонической переработке аккумулируемых толщ базальных тиллов. Этот процесс получил отражение в формировании тел фронтальных гряд. Достоверно установлены дислокации двух типов - надвиговые и складчатые. Первоначально в ослабленных фронтальных зонах в теле ледника на удалении 1-5 км от него непосредственного края возникали складчатые деформации. Они состояли из смятого в конические или реже цилиндрические складки перенасыщенного дебрисом льда, сохранявшего черты первоначальной сланцеватой текстуры. Но в ряде случаев пульсирующий характер подвижек отдельных языков ледниковой лопасти, а также фронтальные напряжения в теле прикраевой зоне приводили к тому, что пластичное смятие базальных тиллов сменялось надвигами отдельных блоков-чешуй льда на ранее сформированные ядра складок (рис. 3). Запуск этого процесса был связан с краткосрочными увеличениями скорости движения льда. Постепенное насыщение таких фронтальных зон тиллами и тяжелым, моренонасыщенным льдом приводили к отмиранию всей этой узкой полосы ледникового языка. Во время следующей подвижки льда такая зона аккумуляции смещалась в проксимальном направлении относительно края ледникового языка. В результате происходило формирование еще одной цепочки фронтальных моренных гряд, построенной базальным тиллом, смятым в складки. Подобные серии краткосрочных подвижек могут быть связаны с осцилляциями всей ледниковой лопасти (рис. 5). Всего таких краткосрочных подвижек было не менее 6 штук. В пределах поднятий кристаллического фундамента число цепочек гряд уменьшается, что связано с изначально меньшей площадью продвижения активного льда. Наличие серии осцилляций края активного ледника свидетельствуют в пользу фронтального типа 


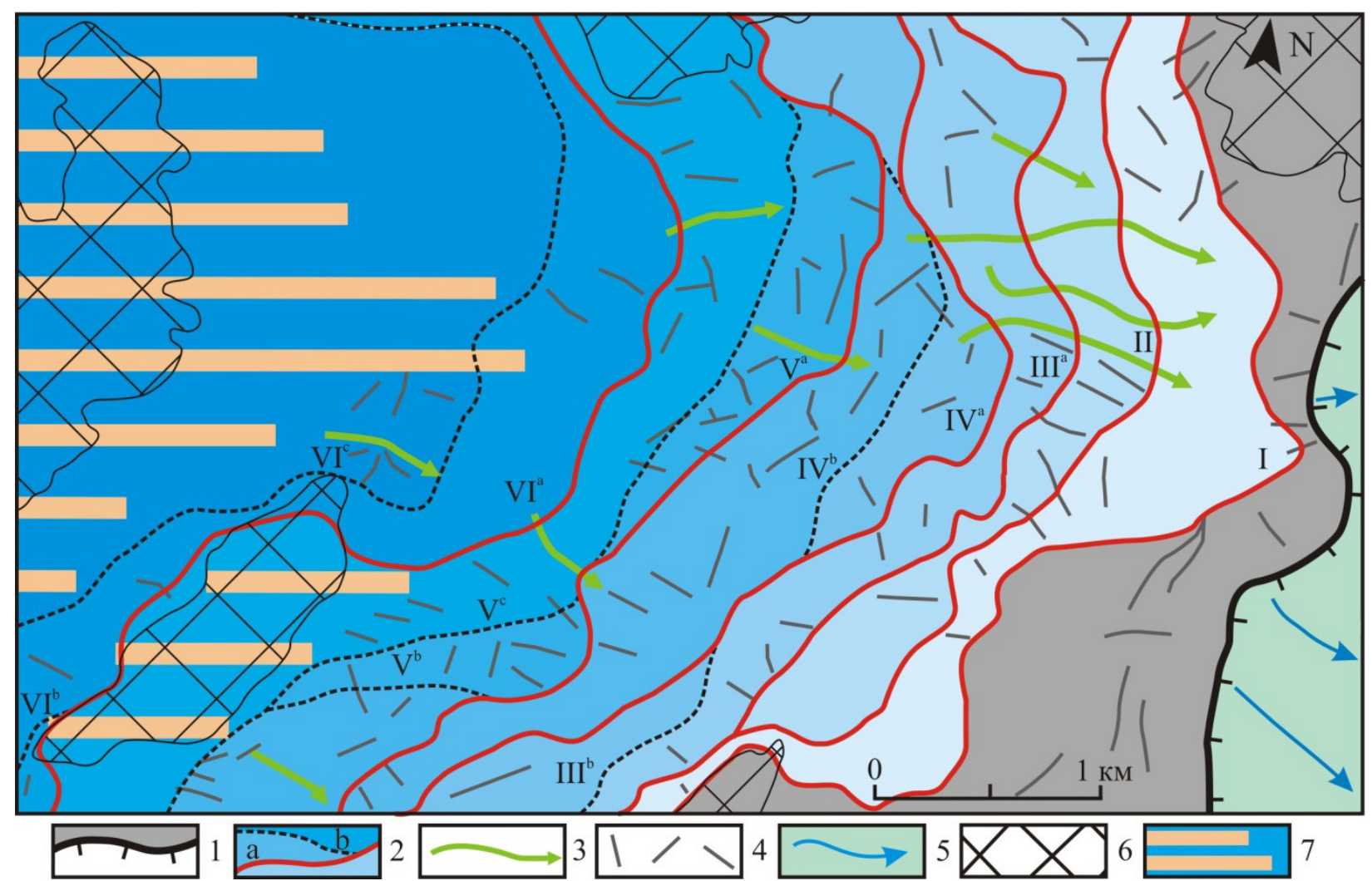

Puc. 5. Схема гляциоморфологических процессов: 1 - край ледника в фазу формирования рельефа района работ; 2 - положение края активного ледника во время осцилляций (а) и положение зон формирования ориентированных цепочек гряд во время осцилляций (b); 3 - положение подлёдных каналов стока талых ледниковых вод; 4 - зоны трещин в теле ледника; 5 - участки аккумуляции флювиогляциальных осадков у края ледника и направления стока талых вод; 6 - поднятия ледникового субстрата; 7 - участки формирования отложений моренной равнины.

дегляциации территории на достаточно коротком временном отрезке. Площадь ледникового покрова в это время практически не сокращалась, край ледника сместился в западном направлении незначительно.

Тело ледникового покрова близ его непосредственного края нарушалось многочисленными трещинами и открытыми подледными полостями, ориентированными перпендикулярно фронту ледника. Эти полости соответствовали потокам талых ледниковых вод и заполнялись флювиогляциальными песчаногравийно-галечными осадками. В ряде случаев эти полости являлись зонами нагнетания перенасыщенного дебрисом «тяжелого» льда. Этот процесс в районе работ проявляется в виде ассиметричных конических гляциоскладок нагнетания с зеленовато-серым базальным тиллом в ядре и флювиогляциальными осадками на крыльях. Часть флювиогляциальных аккумуляций в складку нагнетания могла не включаться и в таком случае дислоцировалась в структуры неустановленного типа (рис. 4).

Следующий этап формирования связан с омертвлением широкой полосы ледниковой лопасти и деградацией ледникового покрова. Лопасть баренцевоморского ледникового покрова потеряла связь с активным ледниковым щитом на обширном пространстве в 60 км к северу и 150 км к западу от района исследования. В это время подлёдные каналы стока талых леднико- вых вод продолжили своё существование и сформировали большую массу флювиогляциального материала, как во внутриледниковой области, так и за фронтом массива мертвого льда. Во внутриледниковой области наиболее крупные каналы стока были заложены в самых низких местах залегания ледникового субстрата. Так, в районе работ они расположены на участке, унаследованном современной долиной $\mathrm{p}$. Мартимъявръйок, где в настоящее время расположены наиболее выраженные в рельефе радиальные гряды, построенные флювиогляциальными осадками. Зафронтальные флювиогляциальные аккумуляции проявляются по понижениям коренного рельефа в виде площадок долинных зандров. Контрастное выражение в структуре стагнирующего массива льда приобретали зоны трещин и нарушений ледника зоны наименьшего давления блоков мертвого льда. На контакте мертвого льда и ледникового субстрата, построенного рыхлыми, пластичными, водонасыщенными осадками формировались малоамплитудные конические гляциоскладки сжатия, в которые вовлекались отложенные ранее базальные тиллы $[10,12]$. Эти складки выражены в виде большинства кольцевых гряд района работ. После таяния массы мертвого льда, на уже существующие ядра гряд фронтального, кольцевого и радиального типов, произошел снос абляционного тилла перлювиальной фации. Этот 
тилл залегает в виде покрышки различной мощности (до 1 м в пределах гряд, 0,2-0,4 м в пределах моренной равнины) и фиксируется во всех обнажениях в районе работ.

Таким образом, нами установлены закономерности размещения грядового рельефа в пределах краевых зон последнего оледенения. Здесь среди хорошо выраженных форм кольцевого рельефа часть гряд расположены закономерно, параллельно или перпендикулярно относительно края ледникового покрова. Выявлено, что ведущим рельефообразующим процессом при формировании фронтальных и кольцевых гряд была гляциотектоническая переработка рыхлого ледникового материала в виде складок и надвигов, а при формировании радиальных гряд - флювиогляциальная аккумуляция в подледниковых каналах стока талых вод. Дегляциация на севере Кольского полуострова происходила путем смены фронтального типа на ареальный. Фронтальный тип дегляциации связан с формированием узких полос грядового рельефа и был связан, по нашему мнению, с похолоданиями в позднем плейстоцене. Во время потеплений ледник терял способность к перемещению сразу на большой территории, что приводило к переходу к ареальной дегляциации территории.

Новые материалы будут использованы в дальнейших работах по установлению особенностей ледникового морфогенеза и особенностей динамики последнего ледникового покрова в Кольском регионе. Установленные закономерности строения ледникового рельефа краевой зоны могут служить критериями прогнозирования минерального строительного сырья: песков, песчано-гравийных смесей, галечно-валунных смесей.

Авторы выражают благодарность В. В. Колька, О. П. Корсаковой и С. В. Мудруку за помощьь при подготовке статьи, а также Д. С. Толстоброву за активное участие в полевых работах.

\section{ЛИТЕРАТУРА}

1. Евзеров, В. Я. Краевые ледниковые образования позднего дриаса в северной и центральной частях Кольского полу- острова / В. Я. Евзеров, Е. О. Горбунов, В. В. Колька // Четвертичные отложения и новейшая тектоника ледниковый областей Восточной Европы. сб. науч. тр. - Апатиты, 1993. - C. 26-38.

2. Евзеров, В. Я. Строение и формирование внешней полосы одного из поясов краевых образований поздневалдайского ледникового покрова в Кольском регионе / В. Я. Евзеров // Вестник Воронеж. гос. ун-та. Сер. Геология. - 2015. - № 4. - C. $5-12$.

3. The Late Pleistocene interglacial, late glacial landforms and Holocene neotectonics of the Kola Peninsula / V. Kolka [et. al.] // ICG excursion, № 34, August 14-23, 2008. - 72 p.

4. Евзеров, В. Я. Пояса краевых ледниковых образований Кольского региона / В. Я. Евзеров, С. Б. Николаева // Геоморфология. -2000 . - № 1. - С. 61-73.

5. Арманд, А. Д. Краевые зоны валдайского оледенения на Кольском полуострове / А. Д. Арманд, Н. Н. Арманд // Последний Европейский ледниковый покров. сб. науч. тр. - М: Наука, 1965. - С. 44.

6. Арманд, Н. Н. Грядово-кольцевой рельеф морены / Н. Н. Арманд // Рельеф и геологическое строение осадочного покрова Кольского полуострова. сб. науч. тр. - М.-Л.: Наука, 1964. - С. 48-54.

7. История формирования рельефа и рыхлых отложений северо-восточной части Балтийского щита / С. А. Стрелков [и др.]. - Л.: Наука, 1976. - 164 с.

8. Лаврова, М. А. Четвертичная геология Кольского полуострова / М. А. Лаврова. - М.-Л.: Наука, 1960. - 233 с.

9. Колька, В. В. Мунозерская островная возвышенность / В. В. Колька // Вестник Мурманского государственного технического университета. - 1998. - Т.1. - № 3. - С. 79-88. 10. Аболтиньш, О. П. Гляциоструктура и ледниковый морфогенез / О. П. Аболтиньш. - Рига: Зинатне, 1989. - 284 с.

11. Stroeven, A. P. Degaciation of Fennoscandia / A. P. Stroeven [et al.]. // Quaternary Science Reviews. - 2016. - p. 1-31.

12. Каплянская, Ф. А. Гляциальная геология: Методическое пособие по изучению ледниковых образований при геологической съемке крупного масштаба / Ф. А. Каплянская, В. Д. Тарноградский. - Санкт-Петербург: Недра, 1993. - 328 с. 13. Семенова, Л. Р. Ледниковая геология Кольского полуострова (поздний плейстоцен): автореф. дис. .. канд. геол.мин. наук. / Л. Р. Семенова. - Санкт-Петербург, ВСЕГЕИ, 2004. $-23 \mathrm{c}$.

14. Евзеров, В. Я. Литология морены поздневалдайского оледенения западной части Кольского полуострова / В. Я. Евзеров // Вестник Мурманского государственного технического университета. - 2017. - Т. 20. - № 1-1. - С. 48-59.
Геологический институт - обособленное подразделение Федерального государственного бюджетного учреждения науки Федерального исследовательского иентра "Кольский научный иентр Российской академии наук", г. Апатиты

Вашков Андрей Александрович, кандидат геологоминералогических наук, научный сотрудник

E-mail:vashkov@geoksc.apatity.ru

Тел.: +7 (81555) 79571

Носова Ольга Юрьевна, аспирант, инженер

E-mail: nosova@geoksc.apatity.ru; Тел.: +7 (81555) 79571

\section{Geological Institute of Kola Scientific Centre of RAS, Apatity}

Vashkov A. A., Candidate of Geological and Mineralogical Sciences, researcher

E-mail:vashkov@geoksc.apatity.ru

Tel.: +7 (81555) 79571

Nosova O. Yu., postgraduate student, engineer

E-mail:nosova@geoksc.apatity.ru

Tel.: +7 (81555) 79571 